\title{
KUI LAPSEGA EI RÄÄGI ÜKSNES EMA: VALIK TERMINEID EESTI LASTE- JA HOIDJAKEELE KOHTA
}

\author{
Helen Kõrgesaar, Airi Kapanen
}

Ülevaade. Paralleelselt lastekeele ja selle omandamise uurimisega on Eestis viimastel kümnenditel uuritud lastekeelega tihedalt seotud hoidjakeelt. Erinevalt eesti keelest on neid kaht keelevarianti võõrkeelses teaduskirjanduses nimetatud mitme eri terminiga, eesti keeles on piirdutud üksnes lastekeele, hoidjakeele ja lapsele suunatud kõnega, mis aga ei anna laste- ja hoidjakeeleuurijatele piisavat hulka vajalikke ja täpseid töövahendeid. Terminite ja nende mõistesisu paljude tõlgenduste tõttu on praeguseks kujunenud vajadus määrata kindlaks lapsele suunatud kõne eri kasutusjuhud, kuna eri vanuses ja eri lähedusastmes olevate lastega räägitakse isemoodi.

Et vältida segadust, kus autori eelistustest lähtuvalt on ühe terminiga tähistatud mitut mõistesisu, on siinse artikli eesmärk ühelt poolt avada võõrkeelses teaduskirjanduses käibel olevate terminite mõistesisu ning teiselt poolt neid täpsustada ja anda soovitusi, kuidas võiks neid termineid edaspidi eesti laste- ja hoidjakeele uurimisel kasutada.*

Võtmesõnad: esimese keele omandamine, lapsele suunatud kõne, isade kõne, emade kõne, terminivara, eesti keel

\section{Sissejuhatus}

Kas lastega kõneldes kasutatakse üksnes mugandatud keelevarianti? Kas igas vanuses lastega kõneldakse alati ühtmoodi? Kas kõik täiskasvanud räägivad lastega ühtmoodi? Kas kaheaastasele lapsele ja täiskasvanud lapsele suunatud kõnet võiks tähistada ühe ja sama terminiga? Kes on täiskasvanud laps? Kuhu tõmmata piir, mis vanusest alates laps ei ole enam laps? Nii laste- kui ka hoidjakeele uurimisse süvenedes tekib uurijal rohkelt küsimusi, mis annab tunnistust erialaselt tunnetatud vajadusest erinevate, sisult täpsete terminite järele. Siit ka küsimus - kas selleks, et kirjeldada, kuidas laps keelt omandab ja täiskasvanu seda toetab, piisab ainuüksi

* Autorid tänavad retsensente hoolika süvenemise ja asjakohaste märkuste eest. 
termineist lastekeel ja hoidjakeel, kui vaadeldavad lapsed võivad olla mis tahes vanuses (eeldusel, et ka täiskasvanud laps on kellegi laps), suhtluskontekst võib olla isesugune, lapsega vestlejaks võib peale ema olla ka isa, tädi-onu, õde-vend, vanavanem, lapsehoidja, peretuttav?

Laste endi kõne kohta kasutatav termin lastekeel keeleuurijatele probleeme ei valmista - lastekeel on laste endi produtseeritav keel, mis muutub vastavalt lapse vanusele. ${ }^{1}$ Inglise keeles on lastekeele kohta paralleelselt kasutusel terminid child language ja first language (õdede-vendade omavahelise vestluse puhul ka peer talk), mille mõistesisu on üsna üksühene. Lastekeele uurimise juures pole seni olnud märgata vajadust lisada lastekeele mõistele kõrval-või alammõisteid, kuivõrd (erinevalt hoidjakeelest) seda keelevarianti kõneleb ainult laps ise, olenemata sellest, et see muutub ja täiustub aja jooksul, läbides eri etappe ja sarnanedes lõpuks üha enam täiskasvanute kõnega. Lastekeele uurimisel on lapse bioloogiline vanus kõige täpsem eristaja.

\section{Lastekeele kohta varem kasutatud termineid}

Terminit lastekeel kasutatakse enamasti keelevariandi kohta, mis pole veel jõudnud sihtkeele ehk täiskasvanupärase keele kõiki tunnuseid omandada. Lastekeele mõistesisu ei hõlma üksnes lihtsustatud leksikat, vaid kindlasti kuuluvad lastekeele alla ka žestid, vokaliseerimised, samuti eriomane loov ja väljendusrikas keelekasutus, mille abil laps täiskasvanu tähelepanu püüab ja kontakti hoiab, ning laste kuuldavaks tehtud sisekõne (ingl private speech).

Üks esimesi, kes Eestis pani tähele keelekasutuse erinemist sõltuvalt kõneleja vanusest, oli Julius Mägiste ${ }^{2}$ (1924). Kuigi ta on märganud, et on olemas lastekeel ja ammede keel, teeb ta seda muu jutu seas ega erista kaht keelevarianti termini tasandil, liiatigi kasutab ta saksa keele termineid Kindersprache ja Ammensprache üksnes lastekeele tähistamiseks, kuigi tänapäeva keeleteaduses tähistab esimene laste- ja teine hoidjakeelt. Mägiste eristab eaklasside alusel lastekeele, nooremapõlve keele ja vanema-põlve keele (viimase all on silmas peetud täiskasvanukeelt) ning jätab targu tõmbamata täpse vanusepiiri, millal üleminek ühelt keelevariandilt teisele aset leiab. Pöörates tähelepanu lapse keele üleminekule noorema-põlve keeleks ütleb Mägiste, et "kõne õppimisel esimesi samme tegeva lapse ja puberteedile ligineva lapse vahel on määratu vahe, mis peegeldub kõige teravamalt nende keeles kui väljendusvahendis" (Mägiste 1924: 3). Keelte eespool mainitud jagunemist eaklasside alusel silmas pidades leiab Mägiste, et kõige iseseisvam neist on lastekeel (sks Kindersprache, Ammensprache). Siit nähtub, et Mägiste paigutab lastekeele ja hoidjakeele ühe nimetuse alla (Kindersprache 'lastekeel', Ammensprache 'hoidjakeel, ammekeel') (Mägiste 1924: 2).

Mägiste kasutab terminiga lastekeel paralleelselt ka terminit lastemurre, viidates teiste hulgas ka Saksamaa kasvatusteadlase Berthold Otto artiklile ajakirjas Kindesmundart, kus viimane on püüdnud lastekeelt pedagoogikas tähtsale kohale seada ja on öelnud: "Ligemas tulevikus ei tohi pedagoogi aunime peale

\footnotetext{
1 Artikli autorid on kursis nii terminite kui ka definitsioonidega, mida on kasutatud õigekeelsussõnaraamatus, eesti keele seletavas sõnaraamatus ning muudes üld- ja oskuskeele sõnastikes. Kuigi osas neis allikais on öeldud, et lastekeel ja hoidjakeel on sünonüümid, on see siiski eksitav, kuivõrd tegu on kahe eri mõistesisuga, mida vastavalt tähistavadki kaks eri terminit.

2 Julius Mägiste kutsub Emakeele Seltsi ajakirjas Eesti Keel avaldatud artiklis "Paar sõna lastekeelest" avalikkust üles tegema jõudetundidel ülestähendusi oma lapsepõlvemälestuste ja hilisemate kokkupuudete põhjal laste-ja ammede keelega ning saatma neid Tartu Emakeele Seltsile (Mägiste 1924: 9).
} 
pretendeerida keegi, kes ei valda lastemurret". Termini lastekeel kohta leiab Mägiste, et see "võistluseta läbilöönud nimetus" pole küll päris täpne, kui pidada silmas autoriteetide (ta nimetab Hermann Pauli, Wilhelm Wundti, Hugo Schuchardti ja Adolf Gotthard Noreeni) seisukohta, kelle sõnul "pole lastekeel - nimelt just kui kõrvale jätta kõige varasema lapsepõlve instinktiivsete reflekside keel, nn Lallwörter ('lalin') jm - nii palju laste eneste, kui nende hoidjate, ammede ja muu ümbruse loodud. Need kohandavad oma kõne lastega viimaste kõnekatsete puhul tehtud tähelepanekuile vastavalt lastepärasemaks, ja lastel pole muud kui oma matkimisandi kasutada" (Mägiste 1924: 3). Nii selgubki, et juba ligi sada aastat tagasi on märgatud, et keelevariandid, mida kasutavad lapsed ja mida räägivad nendega teised kõnekogukonna liikmed, on erinevad, ja neid on püütud tähistada eri terminitega.

Väärib ka märkimist, et alates Mägistest ei ole senimaani määratud mingit kindlat vanusepiiri, millal lastekeel lõpeb, kuna tegemist on individuaalse, areneva keelekasutusega ega ole võimalik kindlaks teha mingit ajapiiri, millal see enam ei arene. Eesti keeleomandamisuuringutes on terminiga lastekeel tähistatud enamasti väikelaste ja koolieelikute kõnet, aga mõeldav on kasutada sama terminit ka vanemate laste keele kohta, seda muidugi juhul, kui räägitakse veel arenevast keelest.

\section{Hoidjakeele kohta seni kasutusel olnud termineid}

Tiiu Erelt on "Eesti keele käsiraamatus" maininud lastekeelset ehk ninnutussõnavara (lapsega rääkimine - ninnutamine, kõne - ninnutis), mille alla ta paigutab nii laste endi kui ka lapsehoidjate keeles kasutatavad sõnad (lähemalt vt Erelt jt 2007: 620-621). Siinse artikli autorid leiavad, et mugandatud keelevarianti kasutatakse ka vanemate kui kolmeaastaste lastega kõneldes, ehkki täiskasvanu konkreetsed mugandused sõltuvad lapse vanusest. Erelti kirjeldatud ninnutist võiks ehk pidada hoopis kuni aastasele lapsele suunatud keelekasutuseks, milles tõepoolest on rohkem hüüdsõnu ja -lausungeid ning mille nn pudisõnad kõlavad samuti pigem lapse fonoloogiliselt lihtsate sõnade imitatsioonidena. Patricia Kuhl (eri valdkondade ühisuurimus, vt Gopnik jt 1999), kes on lastekeele uurimisel küll pigem intonatsioonile keskendunud, kirjeldab ema häält kui akustilist konksu, mille eesmärk on püüda beebi tähelepanu ja fokuseerida see kõnelejale. Kuhl arutleb, kas emad kasutavad seda spetsiifilist kõnevarianti ainult beebide tähelepanu võitmiseks või on sellel veel mõni oluline eesmärk, ja kinnitab samas, et ema kõneldud keel aitab esmajärgus lahendada beebide n-ö keeleprobleemi, st võimaldab beebil hakata kõnevoolus sõnu eristama. Kui väikelapsega kõneldakse, on laused lühemad ja lihtsamad, samu asju korratakse (sageli ka eri variatsioonidega) üle, alateadlikult on häälikud moodustatud selgemalt ja neid hääldatakse korrektsemalt kui täiskasvanuga suheldes, konsonandid ja vokaalid on pikendatud ja argikeelega võrreldes hääldatud liialdatud selgusega. Kuhl on seisukohal, et sellise keelevariandi omadused, mida emad kasutavad beebiga suheldes, võivad aidata neil aru saada emakeele sõnadest ja grammatikast (Gopnik jt 1999).

Kui vaadelda laste- ja hoidjakeele uurimist sugulaskeelte hulgas, võib märgata, et näiteks Soome lastekeeleuurijad on möödunud sajandi 1990. aastatel näinud samuti vajadust täiskasvanult lapsele suunatud keelevarianti märkivat terminit 
täpsustada. 1993. aastal arutleb Kirsti Toivainen soome lastekeele uurimise juures kasutatavate terminite hoivakieli ('hoidjakeel') ja hoivasana ('hoidjasõna') üle. Tema sõnul võivad need terminid hoolimata oma semantilisest selgusest harilikule keelekasutajale harjumatud tunduda, kuid märgivad lingvistikatermineina täiskasvanult lapsele suunatud n-ö pudikeelt ja pudisõnu (sm lepertelykieli ja lepertelysana). Termin hoivakieli loodi tähistama vastet ingliskeelsele terminile baby talk. Toivainen leiab, et terminiga hoivakieli ei tähistata laste eneste arenevat keelt, vaid tegemist on keelevariandiga, mida kasutavad täiskasvanud, kui nad räägivad lapsega. Seetõttu tuleb eristada lastekeelt, hoidjakeelt ja täiskasvanukeelt. (Toivainen 1993)

Sari Kunnari ja Tuula Savinainen-Makkoneni (2004) sõnul tähistatakse terminiga hoivakieli ('hoidjakeel') keelevarianti, mida täiskasvanu räägib lapsega ja mis on n-ö hoidjavärvinguga. Hoidjakeele ülesehitus on lihtsustatud ja olulisi asju korratakse aina üle (nt “Tule siia, tule!”), mis peaks kindlustama, et teade jõuab lapsele kindlasti pärale. Hoidjakeelele on iseloomulikud kõrgem hääletoon ja nähtus, kus üht ja sama mõtet antakse lapsele edasi mitmel eri moel. Hoidjakeele kasutamist põhjustavad ühelt poolt lapse välised omadused (lühike nägu, esiletõusev laup, ümarad silmad, paksud põsed, tema üleüldine väiksus), teiselt poolt tema puudulik suhtlemisoskus, samuti võib hoidjakeele kasutamise põhjuseks olla alateadlik soov õpetada lapsele keelt. Täiskasvanult lapsele suunatud kõne kaudu õpib laps tundma kultuuriomast vastastikust mõjutamist ja ümbritsevat keskkonda. (Kunnari, Savinainen-Makkonen 2004: 88-89)

Tänapäeval on soome lastekeeleuurimustes kasutusel ka termin vauvakieli (ingl baby talk), mida erinevad soome-inglise oskussõnastikud ${ }^{3}$ käsitavad kui emade kõne (ingl motherese) vastet, lisades täpsustuseks, et see on "täiskasvanult lapsele suunatud nn pudikõne".

Ka ingliskeelses teadussõnavaras tähistab lapsega suhtlemist hulk eri termineid ning nende kasutamises valitseb teatav ebaühtlus, et mitte öelda segadus. Reili Argus on lisaks terminile baby talk samuti nimetanud termineid parentese ja motherese ning leiab kõige sagedamini kasutatavama termini olevat sisendkõnet või -keelt tähistava input'i, lisades, et sageli räägitakse ka lapsele suunatud kõnest (ingl child-directed speech, CDS). (Argus 2008: 9) Termin motherese on ingliskeelsetes lastekeeleuurimustes mõningast segadust külvanud, kuna sellega on sageli üldistatult tähistatud igasugust lapsele suunatud keelevarianti ja kasutatud seda hoidjakeele sünonüümina. Catherine E. Snow loobub sel põhjusel 1986. aastal "neologismide" baby talk ja motherese kasutamisest ja kasutab nende asemel terminit child directed speech, kuna termin motherese jätab tema sõnul väära mulje, otsekui räägiks lastega sel erilisel moel ainult emad (Snow 1986, 1997: 69). Kahtlemata tuleb siinkohal Snow'ga nõustuda. Samal seisukohal on Jay Belsky ja Brenda Volling, kes nimetavad terminit motherese eksitavaks ja teevad ettepaneku lisada keeleuurijate professionaalsesse sõnavarasse ka termini fatherese või siis sooga vähem seotud termini parentese (Belsky, Volling 1984), mida mõnel määral on hiljem ka kasutatud, ehkki mitte järjekindlalt.

Põhjendusel, et laps ei suhtle ainult emaga, on lapsele suunatud ja mugandatud kõnet nimetatud ka eesti keeles alates 1990. aastate keskpaigast hoidjakeeleks, on kasutatud ka terminit hoidekeel (nt Pajusalu 1996).

3 Vt nt EUdict http://www.eudict.com/ või Sanakirja.org (2.1.2015). 
Niisiis tundub Erelti pakutud termin ninnutamine käivat vaid keelevariandi ühe tasandi, sõnavara kohta, ent samas ei muganda vanem mitte üksnes leksikat, vaid mugandusi leidub keele muudelgi tasanditel, fonoloogiast süntaksini (Lieven 2008: 187-200). Emade kõne ninnutamiseks nimetamine on aga pigem hinnang. See keelend sobib leksikoni hinnanguliselt laetud sõnade hulka ega kvalifitseeru neutraalseks teadusterminiks, seetõttu leiavad autorid, et edaspidi on kohane kasutada pigem terminit beebikõne ${ }^{4}$, mis tähistab kuni aastasele lapsele suunatud kõnet, kusjuures laps ise ei pruugi osata veel vastu rääkida. Termini kasutuselevõtu poolt kõneleb ka selle laiem tuntus rahvusvahelises lastekeeleuurimises (ingl baby talk, nt Brown 2013).

Nagu lastekeele puhul, nii tuleb ka hoidjakeele kohta märkida, et ei ole võimalik tõmmata täpset vanuselist piiri, kus hoidjakeel lõpeb. Ka täiskasvanud laps on oma vanemate laps ja temaga räägitakse teistmoodi kui teiste sama vanade inimestega. Märkimisväärne on aga see, et mingis (samuti täpsustamata) vanuses leiab vanema ja lapse vahelises suhtluses aset teatav rollide vahetumine ning hoopis laps hakkab kasutama hoidjakeele registrit, kui kõneleb oma vanade vanematega. Niisugune keelevariant on nii gerontoloogia- kui ka neuropsühholoogiauurimustes tuntud kui elderspeak (ka caregivers' speech) ja seda iseloomustavad ühelt poolt valjem hääl, kõrgendatud hääletoon ja vanemlik suhtlusstiil (Balsis, Carpenter 2006) ning teiselt poolt lühemad laused, lihtsamad sõnad, rohked kordused, aeglasem kõne, pikemad pausid jm (Kemper 1994).

\section{Lastekeel ja hoidjakeel kui sotsiolektid}

Siinse artikli autorid, nagu paljud eelviidatud, on seisukohal, et lastekeelt ja hoidjakeelt tuleb kindlasti eristada, ehkki mõlemat keelevarianti iseloomustavad ühtmoodi mitteformaalne kõne ja intiimne, emotsionaalselt lähedane kõnesituatsioon. Hoidjakeelt on vast sobilik nimetada kõneregistriks, millel on oma kindlad tunnused (eripärane intonatsioon, täiskasvanule suunatud kõne lausungitega võrreldes lühemad lausungid, aeglasem kõne, rohked reduplikatsioonid, kordused ja ümberütlemised (Ferguson 1964, Snow, Ferguson 1977, 2013), täiskasvanukõnest erinev lausungite sõnaliigiline koostis, samuti teistsugune pragmaatiline funktsioon (Clark 2011, Argus, Kõrgesaar 2014, Kõrgesaar 2014a jne)) ja mida võib lapsega rääkida ükskõik kes, alates emast ja lõpetades hambaarstiga. Lastekeelt seevastu räägib vaid laps ise - tegemist on lapse enda üha areneva ja muutuva keelekasutusega, mistõttu on lastekeelt sobivam käsitada kui vanuselist dialekti (Mägistel lastemurre). Selle termini ingliskeelset vastet age dialect kasutab inglise laste- ja hoidjakeelt vaadelnud heebrea keeleuurija Anat Ninio (2011), kes nimetab lapse varajast kõnet kui early child speech, mis tema sõnutsi esindab nimelt vanuselist dialekti. Samuti kasutab ta termineid parental register ja child dialect. Ninio ütleb, et on selge, et termin register on varajase lapsekeele tähistamiseks vähem sobilik ja pigem sobib see vanemalt lapsele suunatud kõne (parental child-directed speech) jaoks, nimetades terminiga child directed speech tähistatut inglise keele "eriliseks registriks" (Ninio 2011: 5, 48, 51, 62, 105, 167, Ninio 2014: 1256).

\footnotetext{
4 Termini beebikõne kasutuselevõtu poolt räägib eesti keele kokku- ja lahkukirjutuse üks põhimõtteid tähenduspõhimõte (Erelt jt 2007: 104) -, kuid ka sõnamoodustusprintsiip, mille kohaselt kirjutatakse sihitisliku täiendosaga omaette tähenduse moodustavad ühendid kokku. Viimatinimetatud tüüpi kokkukirjutistes märgib täiendosa objekti, millele põhiosaga väljendatud tegevus on suunatud (Erelt jt 2007: 106). Seega kui kasutada terminit beebikõne, siis väljendab liitsõna täiendosa beebi objekti, kellele põhiosaga kõne väljendatud tegevus on suunatud.
} 
Terminit vanusedialekt kasutab ka Tiit Hennoste (2006), kui selgitab dialekti mõiste eri tähendusi: kohamurret ja sotsiolekti. Sotsiolekti moodustab Hennoste sõnul eri sotsiaalsete kihtide (vanus, sugu, sotsiaalne staatus vms) keelekasutus, mis väljendub peamiselt sõnavaras ja (kõige rohkem) häälduses. Peamiseks erinevuseks laste ja täiskasvanute keelekasutuse vahel ongi, et täiskasvanu mugandab kõnet sõltuvalt lapse vanusest jne, teine aga ei tee seda mitte. Väikelaps ei ole kognitiivselt, sh keeleliselt sama võimekas kui täiskasvanu ja tema suutlikkust keelt kasutada kammitsevad esialgu fonoloogilised, kognitiivsed jm arengupiirangud.

\section{Terminite võimalik jaotus mõistehierarhias}

1994. aastal ilmunud kogumiku "Input and Interaction in Language Acquisition" eessõnas on Catherine Snow loobunud oma varasemast seisukohast (piisab terminist child directed speech, kuna muud terminid külvavad liigset segadust), kirjeldades, kuidas paljud keeleuurijad, teiste hulgas ka kognitivistid, tunnistavad nüüd vajadust info järele sisendkõne kõigi andmete ja lapse keelelise keskkonna kohta, et paremini aru saada, kuidas lapsed keeleüksusi ja -nähtusi õpivad, mõistavad ja kasutavad, ning toob sealsamas näiteid uurimustest beebikõne (baby talk), emade kõne (maternal input) ja õpetajate kõne (teachers' input) kohta (Snow 1994: 3-7).

David Crystali ingliskeelsest lingvistika-ja foneetikasõnaraamatust (2008) leiab aga märksõnade caregiver's speech ja fatherese juurest viite, mis suunab lugeja otsima märksõna motherese. Motherese märgib Crystali järgi terminit, mida kasutati varajastes keeleomandamisuurimustes. Ta ütleb, et pakutud on ka terminit fatherese, kuid seda kasutatakse harva ja mõlemad terminid on koondunud ülemmõiste lapsele suunatud kõne (child-directed speech) alla, mis hõlmab lisaks vanematele ka vanavanemaid, lapsehoidjaid ja teisi, kes lapse eest hoolt kannavad (other carers). (Crystal 2008: 66, 74-75, 186, 316) Samas kõnelevad Heidelbergi Pedagoogikakõrgkooli teadustööaruanded ${ }^{5}$ vajadusest isade ja emade kõnet siiski eristada ning nende keelevariantide tähistamiseks on kasutusel nimelt ingliskeelsed terminid die Motherese (aruandes alates 2003. aastast) ja die Fatherese (aruandes alates 2005. aastast).

Ülaltoodud terminirohkust ja mõistesegadust silmas pidades on siinse artikli autorid koostanud laste- ja hoidjakeele valdkonna edasise uurimise hõlbustamiseks ja terminivaras orienteerumiseks järgmise hierarhilise süsteemi (vt ka soovituslikku terminiloendit artikli lõpus).

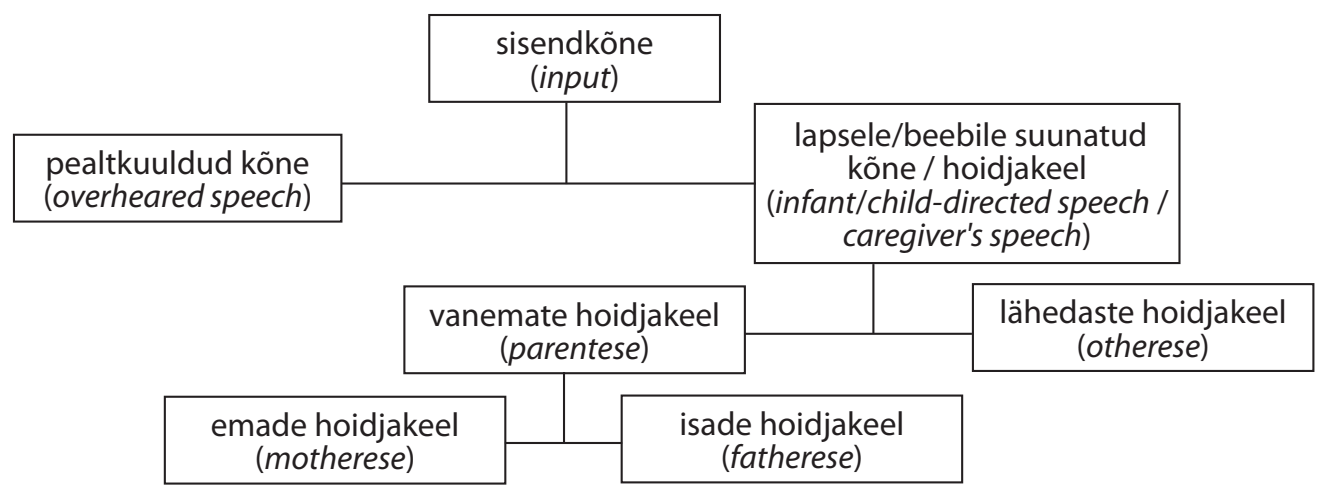

Joonis 1. Soovituslik terminikasutus laste- ja hoidjakeele uurimiseks

5 Vt https://www.ph-heidelberg.de/presse-und-kommunikation/publikationen/forschungsbericht.html (2.1.2015). 
Terminiga sisendkõne tähistatakse ülemmõistet, mis märgib igasugust kõnet, mida laps kuuleb, olgu see siis otse temale suunatud või mitte. Termini pealtkuuldud kõne all on silmas peetud kõike, mis ei ole otse lapsele suunatud, kuid mida laps siiski kuuleb: tele- ja raadiosaated, vestlused bussis, tänaval, kaupluses või arsti ooteruumi ukse taga, ema vestlus külalistega jne. Esineb ka kultuure (nt kaluli rahvas Paapua Uus-Guineas ja Lääne-Samoa), milles ei eksisteeri lapsele suunatud kõnet, vaid lapsed osalevadki suhtluses kui teiste kogukonna liikmete mugandamata keelevariandi pealtkuul(a)jad (ingl overhearers ${ }^{6}$ ) (Ochs, Schieffelin 1995: 78). Pealtkuuldud kõne osatähtsust sisendkõnes ei tohiks alahinnata, kuna see moodustab suurema osa kõnest, mida laps päeva jooksul kuuleb. Joost van de Weijeri (2002) uurimusest selgub, et vaid 14\% kõnest, mida beebi päeva jooksul kuuleb, on otse temale suunatud, 30\% moodustab tema vanematele õdedele-vendadele suunatud kõne ning ülejäänu (enam kui poole) täiskasvanute omavaheline kõne (van de Weijer 2002). Yuriko Oshima-Takane uurimisrühm on uurinud sünnijärjekorra rolli keeleomandamises ja leidnud, et peresse hiljem sündinud lapsed arenevad palju keerukamas keelekeskkonnas kui esmasündinud, kuna kuulevad pealt ka vanematele õdedele-vendadele suunatud kõnet, mis sisaldab nt rohkem isikulisi asesõnu, ja kõne iseenesest, mida nad kuulevad, on samuti märksa täiskasvanupärasem ja komplekssem kui see, mida kuulevad pere esmasündinud (OshimaTakane jt 1996: 631).

Teise alajaotusena (vt joonis 1) on esitatud paralleeljaotised, kus

a) beebile/lapsele suunatud kõne tähistab lapsele suunatud, kuid spetsiaalsete mugandusteta keelt, ning

b) hoidjakeel (ka eesti beebikõne/beebikeel) tähistab lapsele suunatud ja mugandatud keelekasutust. Niisugune eristamine võiks aset leida põhjendusel, et vanem alati ei muganda oma keelekasutust lapsega rääkides ja argiolukorras võib ta suhelda lapse kui täiskasvanud vestluspartneriga, seda eriti suurema lapse puhul.

Mõlema, nii mugandatud kui ka mugandamata keelevariandi saab omakorda jagada kaheks: vanemate ja muude lähedaste (hoidja)keeleks. Vanemate (hoidja) keel omakorda jaguneb emade (hoidja)keeleks (vt Snow, Ferguson 1977, 2013, Newport 1975, Gleitman jt 1984) ja isade (hoidja)keeleks. Autorid on teadlikud, et ingliskeelses teaduskirjanduses ei tehta neil kolmel terminil - vanemate, emade või isade hoidjakeelel (ingl motherese, fatherese ja parentese) - alati kindlat vahet, sageli sel põhjusel, et neid polegi tarvis eristada, kui eesmärk on uurida lapsele suunatud kõnet üldisemalt. Kuna eesti lastekeeleuurimises on teemade valik mitmekesistunud7 , võiks, olenevalt uurija eesmärgist, vajalikud tööriistad terminite näol eesti keeles siiski olemas olla.

Muude lähedaste all (vt joonis 1) mõeldakse kõiki neid, kes lapsega sagedamini kokku puutuvad ja temaga rohkem suhtlevad, avaldades sel moel lapse kõne arengule ka suuremat mõju. Selle jaotuse alla võivad kuuluda õed-vennad ${ }^{8}$ ja lähedasemad omavanused sõbrad (ingl peer talk, vt Blum-Kulka, Snow 2004) ning onudtädid, vanavanemad, peretuttavad, kellega tihemini kohtutakse jpt. Laias laastus võib siia paigutada ka lapsehoidjad, lasteaia- ja hiljem kooliõpetajad, treenerid jts, ehkki nii pedagoogika- kui ka keeleuurimustes vaadeldakse eraldi ka õpetaja-õpilase vahelist suhtlust (ingl teachers' speech, vt Gleason 2013, Owen 1996, Snow 1994).

6 Erinevate kuulajaskonna tüüpide kohta, nagu adressee, auditor, overheared ja eavesdropper, vt Meyerhoff 2006: 43.

7 Eestis on isa ja tütre vestlust uurinud Andriela Rääbis (2012) ning erinevusi isade-emade keelekasutuses Helen Kõrgesaar (2014b, 2014c).

8 Õe ja venna omavahelist suhtlust on uurinud Tuuli Paalandi (2013). 
Kuigi ingliskeelses lingvistikakirjanduses käsitatakse enamikku mainitud termineid sünonüümidena, ei tarvitse see peegelduda eesti teaduskeeles. Selleks et eesti oskuskeel ja eriti selle tuumosana teaduskeel oleks konkreetne ja täpne, tuleb termineid kasutada võimalikult järjekindlalt (Nemvalts 2011: 165). Ingliskeelse teaduse terminisegaduse on tinginud tohutu suur uurijate-publitseerijate hulk ja nii on mõistagi keeruline ühtsust saavutada. Eestis on laste- ja hoidjakeele uurijate ring üsna kitsas, mistõttu selgete, täpsustatud terminite kasutuselevõtt oleks ühtaegu hõlpus ja valdkonnale igati kasulik. Otstarbekas oleks täpsustada ka muid valdkonnas rohkem või vähem kasutatavaid termineid (nt keelekogus, ingl amount of language) ning selgitada põhjalikumalt erinevusi kirjaliku teksti ja suulise kõne uurimisel kasutatavate terminite vahel.

\section{Kokkuvõtte asemel}

Artiklis on lähtutud Uno Mereste ületuspõhimõttest, mille kohaselt teistest hiljem mingil erialal termineid korrastav keel on soodsamas olukorras, sest saab teiste keelte piisamatusi avastada ja vältida, lähtuda erialade mõistesüsteemidest ja kasutada nii oma keele loomevõimsust kui ka laenuvõimalusi (Uno Mereste 2000: 77). Nagu siinse artikli ülevaates viidatud, on inglise keeles kasutatavaid termineid nii laste- kui ka hoidjakeele eri variantide kohta palju, kuid terminikasutuses pole järjepidevust, osa terminite mõistesisu kattub, kuid osa ei peegelda täpselt sedasama eesti keeles. Lisaks on kasutusel palju paralleelvorme, mida valdkonda süvenematu inimene tõlgendab tihtipeale valesti, kuna pole toetavat konteksti (nt hoidjakeele vaste motherese märgib sageli ka isade hoidjakeelt või kelle tahes kõnet, mis on suunatud lapsele).

Kokkuvõtte asemel esitavad autorid soovitusliku laste- ja hoidjakeele terminite loendi emma-kumma valdkonna uurijate töö edaspidiseks hõlbustamiseks.

\section{Soovituslik terminiloend}

beebikõne (ingl baby talk) - täiskasvanult beebile suunatud mugandatud keelevariant

beebile suunatud kõne (ingl infant directed speech) - täiskasvanult beebile suunatud mugandamata keelevariant

emade hoidjakeel (ingl motherese, maternal speech, mother-child interaction/ communication) - emalt lapsele suunatud mugandatud keelevariant

hoidjakeel (ingl caregivers' speech, motherese, maternal speech, mother-child interaction/communication) - täiskasvanult lapsele suunatud mugandatud keelevariant

isade hoidjakeel (ingl fatherese, paternal speech, father-child interaction/communication) - isalt lapsele suunatud mugandatud keelevariant

lähedaste hoidjakeel (ingl otherese) - onude-tädide, vanavanemate, peretuttavate, aga ka lapsehoidjate, lasteaia- ja kooliõpetajate, treenerite jt kõne

lapsele suunatud kõne (ingl child-directed speech) - täiskasvanult lapsele suunatud mugandamata keelevariant 
lastekeel (ingl child language) - lapse enda arenev keelevariant

pealtkuuldud kõne (ingl overheared speech) - kõne, mida laps kuuleb, kuid mis ei ole mugandatud ega otseselt temale suunatud (ühissõidukites, tänaval, telerist jm)

sisendkõne (ingl input) - igasugune kõne, mida laps kuuleb, olgu see siis otse temale suunatud ehk mugandatud või mitte

õdede-vendade ja lähedaste omavanuste sõprade kõne (ingl peer talk) keelevariant, mida laps kasutab suhtluses õe-venna või sõpradega

õpetaja-õpilase vahelise suhtluse keel (ingl teachers' speech)

\section{Viidatud kirjandus}

Argus, Reili 2008. Eesti keele muutemorfoloogia omandamine. [Acquisition of Morphology in Estonian.] Tallinna Ülikooli humanitaarteaduste dissertatsioonid 19. Tallinn: Tallinna Ülikooli Kirjastus.

Argus, Reili; Kõrgesaar, Helen 2014. Sõnaliigid eesti lapse kõnes ja lapsele suunatud kõnes. [Word classes in the child's speech and in the child-directed speech.] - Eesti Rakenduslingvistika Ühingu aastaraamat, 10, 37-53. http://dx.doi.org/10.5128/ERYa10.03

Balsis, Steve; Carpenter, Brian B. 2006. Evaluations of elderspeak in a caregiving context. Clinical Gerontologist, 29 (1), 79-96. http://dx.doi.org/10.1300/Jo18v29no1 07

Belsky, Jay; Volling, Brenda L. 1987. Mothering, fathering, and marital interaction in the family triad during infancy. - Phyllis W. Berman, Frank A. Pedersen (Eds.). Men's Transitions to Parenthood: Longitudinal Studies of Early Family Experience. Psychology Press, 37-63.

Blum-Kulka, Shoshana; Snow, Catherine E. 2004. Introduction: The potential of peer talk. Discourse Studies, 6 (3), 291-306. http://dx.doi.org/10.1177/1461445604044290

Brown, Roger 2013 [1977]. Introduction. - Catherine E. Snow, Charles A. Ferguson (Eds.). Talking to Children: Language Input \& Acquisition. New York: Cambridge University Press, 1-27.

Clark, Eve V. 2011 [2003]. First Language Acquisition. Cambridge: Cambridge University Press.

Crystal, David 2008. A Dictionary of Linguistics and Phonetics. 6th ed. Oxford: Blackwell. http://dx.doi.org/10.1002/9781444302776

Erelt, Tiiu; Erelt, Mati; Ross, Kristiina 2007. Eesti keele käsiraamat. 3. täiendatud trükk. Tallinn: Eesti Keele Sihtasutus.

Ferguson, Charles 1964. Baby talk in six languages. - American Antropologist, 66 (6), 103-114. http://dx.doi.org/10.1525/aa.1964.66.suppl_3.02a0006o

Gleason, Jean Berko 2013 [1977]. Talking to children: Some notes on feedback. - Catherine E. Snow, Charles A. Ferguson (Eds.). Talking to Childen: Language Input and Acquisition. New York: Cambridge University Press, 199-205.

Gleitman, Lila; Newport, Elissa L.; Gleitman, Henry 1984. The current status of the motherese hypothesis. - Journal of Child Language, 11 (1), 43-79. http://dx.doi.org/10.1017/ S0305000900005584

Gopnik, Alison; Meltzoff, Andrew; Kuhl, Patricia 1999. The Scientist in the Crib: Minds, Brains, and How Children Learn. New York: William Morrow \& Co.

Hennoste, Tiit 2006. Suuline keel 1. Keelekõrv. Eetris 4.3.2006. ERR-i arhiivis http://arhiiv. err.ee/vaata/keelekorv-keelekorv-suuline-keel-1 (16.10.2014).

Kemper, Susan 1994. Speech accommodations to older adults. - Aging, Neuropsychology, and Cognition, 1 (1), 17-28. http://dx.doi.org/10.1080\%2fog289919408251447

Kunnari, Sari; Savinainen-Makkonen, Tuula 2004. Mistä on pienten sanat tehty. Lasten äänteellinen kehitys. Helsinki: WSOY. 
Kõrgesaar, Helen 2014a. Küsimused eesti lapsele suunatud kõnes leedu ja vene keele taustal. [Interrogatives in Estonian child-directed speech.] - Eesti Rakenduslingvistika Ühingu aastaraamat, 10, 193-207. http://dx.doi.org/10.5128/ERYa10.12

Kõrgesaar, Helen 2014b. Eesti isade-emade hoidjakeel: kes küsib, kes käsutab, kes räägib rohkem? [Estonian fathers' and mothers' child-directed speech: Who asks more questions, who gives orders, and who speaks more?] - Krista Kerge (Toim.). Uurimusi keele omandamisest, õppimisest ja korpustest. Tallinna Ülikooli eesti keele ja kultuuri instituudi toimetised 16. Tallinn, 59-82.

Kõrgesaar, Helen 2014c. Direktiivsed kõneaktid ja nende kasutamise dünaamika isa-ema kõnes: juhtumiuuring. [Directive speech acts and the dynamics of their usage in father's and mother's speech: A case study.] - Rakenduslingvistika Ühingu aastaraamat, 11, 159-175. http://dx.doi.org/10.5128/ERYa11

Lieven, Elena 2008. Language development: Overview. - Marshall M. Haith, Janette B. Benson (Eds.). Encyclopedia of Infant and Early Childhood Development. Oxford: Elsevier, 187-200.

Mereste, Uno 2000. Oskuskeele üldprobleeme kaug- ja lähivaates. - U. Mereste. Oskuskeel ja seaduste keeleline rüü. Tallinn: Eesti Keele Sihtasutus, 57-83.

Metsmägi, Iris; Sedrik, Meeli; Soosaar, Sven-Erik 2012. Eesti etümoloogiasõnaraamat. [Etymological Dictionary of Estonian.] Tallinn: Eesti Keele Sihtasutus.

Meyerhoff, Miriam 2006. Introducing Sociolinguistics. London-New York: Routledge.

Mund, Argo 2004. Mitmuse omastav luubi all. [Focus on plural genitive.] - Maire Raadik (Toim.). Keelenõuanne soovitab 4. Tallinn: 138-141.

Mägiste, Julius 1924. Paar sõna lastekeelest. [A few words on child-language.] - Eesti Keel, $1,1-9$.

Nemvalts, Peep 2011. Terminiteadusest eesti teaduskeeleni. [From terminology science to academic Estonian.] - P. Nemvalts (Toim.). Eesti teaduskeel ja terminikorrastus. Tallinna Ülikooli eesti keele ja kultuuri instituudi toimetised 13. Tallinn: 136-171.

Newport, Elissa L. 1975. Motherese: The Speech of Mothers to Young Children. La Jolla: Center for Human Information Processing, University of California, San Diego.

Ninio, Anat 2011. Syntactic Development, Its Input and Output. Great Britain: Oxford University Press. http://dx.doi.org/10.1093/acprof:0so/9780199565962.001.0001

Ninio, Anat 2014. Learning a generative syntax from transparent syntactic atoms in the linguistic input. - Journal of Child Language, 41 (6), 1249-1275. http://dx.doi. org/10.1017/S0305000913000470

Oshima-Takane, Yuriko; Goodz, Elizabeth; Derevensky, Jeffrey L. 1996. Birth order effects on early language development: Do secondborn children learn from overheard speech? Child Development, 67 (2), 621-634.

Ochs, Elinor; Schieffelin, Bambi 1995. The impact of language socialization on grammatical development. - Paul Fletcher, Brian MacWhinney (Eds.). The Handbook of Child Language. Oxford: Basil Blackwell, 73-94.

Owen, David 1996. Do teachers modify their speech according to the proficiency of their students? - English Language Teacher Education and Development, 2 (1), 31-51.

Paalandi, Tuuli 2013. Õe ja venna omavahelise spontaanse suhtlustegevuse keelelised erijooned mängusituatsioonis: küsimused ja direktiivid. Bakalaureusetöö. Tallinna Ülikool.

Pajusalu, Karl 1996. Eesti hoidekeele kujunemine. - Suomalaiskielten omaksumista tutkimassa. Turun yliopiston suomalaisen ja yleisen kielitieteen laitoksen julkaisuja 53. Turku: Turun yliopisto, 117-124.

Rääbis, Andriela 2012. Direktiivskventsid isa ja tütre suhtluses: juhtumianalüüs. [Directive sequences in a conversation of father and daughter: A case study.] - Rakenduslingvistika Ühingu aastaraamat, 8, 213-230. http://dx.doi.org/10.5128/ERYa8.14 
Snow, Catherine E. 1994. Introduction. - Clare Gallaway, Brian J. Richards (Eds.). Input and Interaction in Language Acquisition. Cambridge University Press, 3-12.

Snow, Catherine E. 1997 [1986]. Conversations with children. - Paul Fletcher, Michael Garman (Eds.). Language Acquisition. Cambridge University Press, 69-89.

Snow, Catherine E.; Ferguson, Charles A. 2013 [1977]. Talking to Children: Language Input and Acquisition. New York: Cambridge University Press.

Toivainen, Kirsti 1993. Hoivakielen tutkimuksesta ja suomen murteiden hoivasanastosta. Ettekande käsikiri soome-ugri keelte omandamise uurimise II seminarilt Nauvo Seilis 25. sept 1993.

Weijer, Joost van de 2002. How much does an infant hear in a day? - Ettekanne. GALA'2001 Conference on Language Acquisition. Lisboa.

Helen Kõrgesaar (Tallinna Ülikool) uurib eesti hoidjakeelt, selle dünaamikat ja mõju lapse kõne arengule.

Narva mnt 25, 10120 Tallinn, Estonia

helen.korgesaar@gmail.com

Airi Kapanen (Tallinna Ülikool) uurib eesti laste keeleomandamist, täpsemini süntaksi arengut ja komplekssust.

Narva mnt 25, 10120 Tallinn, Estonia

airikapanen@gmail.com 


\section{WHEN THE MOTHER IS NOT THE ONLY \\ ONE TALKING TO A CHILD: SELECTION \\ OF TERMS IN ESTONIAN CHILD LANGUAGE AND CAREGIVERS' SPEECH}

\section{Helen Kõrgesaar, Airi Kapanen}

Tallinn University

The article focuses on specifying and describing the terms used in Estonian child language and child-directed speech. The terms used now do not offer enough necessary and precise tools for researchers of child language. Since children of different ages and proximities are talked to differently, a need has arisen to define the different types of child-directed speech, due to the multiple interpretations of terms and their concepts. Although most of the terms describing speech directed from an adult to a child have been considered synonyms in the English linguistics literature, this might not be the case in Estonian scientific language. The confusion of terms in English science is due to the massive amount of researchers and publishers which obviously makes it difficult to achieve uniformity. Taking into consideration this multitude of terms and confusion of concepts, the authors of this article offer recommended terms to be used in the future research of child and child-directed speech, in order to simplify the research and facilitate understanding of the terminology. The circle of researchers of child and child-directed speech in Estonia is quite narrow, which not only makes the implementation of clear, specified terms easy to agree on but would also greatly benefit the field of research itself. The authors are aware that in English scientific literature the terms used (e.g. motherese, fatherese, parentese) are not strictly distinctive, often due to the fact that it is not necessary, if the aim is to research child-directed speech in general. Since Estonian child language research is diversified, the necessary tools in the form of Estonian-language terms should be provided to be used according to the aim of the researcher.

Keywords: first language acquisition, child-directed speech, fatherese, motherese, lexicon of terms, Estonian 